\title{
Introduction: Confronting the future, confronting the past
}

\author{
Martin Doornbos and A Haroon Akram-Lodhi
}

\section{'Things fall apart' 1 : a personal retrospective of Fiji in 1987}

It was October 1987, and one of the authors was at a social gathering in Suva. One of the guests told the gathering: 'there is the body of a dead soldier lying in the morgue, but the relatives are not being informed'. The guests being addressed allowed the announcement to sink in for a moment. The key point was then made: 'the question of course is why not?'.

This was evidently not an unknown soldier. However, this made the question only more compelling. One of the others present provided further details, which sharpened the point: 'apparently, they are having some difficulty with the cause of his death. Will (Colonel Sitiveni) Rabuka be facing greater public embarrassment if the man has been killed by an opponent of the coup, or if he turns out a victim of a liquidation within the army?'. A third speaker reflected: 'Rabuka evidently cannot use either. Yet, an internal reckoning strikes me as the most likely explanation; who else has weapons in this country, or at least at this point in time?'.

It was a month since the second coup of 1987. In the absence of newspapers and uncensored radio, rumour and speculation was passed on and exchanged continuously. That is, until the evening, when everybody rushed home before the nine o'clock curfew. Before reaching home, one had to pass more than one checkpoint, a new experience to all who lived in Fiji. A spokesman for the military government on the radio offered the encouraging news that the number of burglaries had gone down since the curfew was introduced. 
The announcement of new decrees by the military government was greeted with an air of sceptical misgiving. If someone had the texts, people found out that the army and the police were allowed to shoot at people that had caused disturbances, and could not afterwards be held liable for murder. People found out that suspected elements could be detained by the security forces without prior notice. People found out that if they were detained, a panel would be constituted with the power to give non-binding advice about possible release after a month's detention. If the advice was ignored, the panel would meet again in six months.

People, such as several members of staff of the University of the South Pacific (USP), were detained, and thrashed, without justification. The regime did indeed use harsh methods to intimidate its opponents, and this no doubt muted broad open protest, which was surprisingly absent. Thus, about 120 names were entered on a list of people who were prohibited to leave the country, out of fear for the damage they might cause to Fiji's image abroad. The perversity of the situation was apparent. As one of those listed asked, 'would not the existence of that list itself be much more damaging to the national image?'. Despite this, though, there were relatively few acts of violence, in large part because a structural basis for violence did not exist. There was, admittedly, some social friction, particularly in informal contexts. At the time though there seemed little doubt that both Indo-Fijians and most indigenous Fijians were not particularly happy with the installation of the military regime.

Despite the lack of opposition, the tranquility of Fiji had been shattered, and the desperation that came in the wake of the new situation was pervasive. 'It is inconceivable and incomprehensible', a Dutch lecturer at USP remarked, 'to see such a wonderful and truly multicultural society collapse within such a short while. I cannot and I will refuse to believe that all this will really be destroyed'. A British physicist recounted how after eleven years of work in Fiji he had decided to apply for citizenship. 'At the moment of the first coup I stood in the queue for the immigration office. It was like hearing God's voice. Now, after the second coup, I have resigned.'

Indo-Fijians felt the most desperation. Their future appeared very gloomy, with every day bringing new, deeply demoralising measures. Calls such as 'throw Indians out' and 'Fiji for Fijians' were heard, reflecting sentiments which from time to time had been articulated 
amongst a particular sub-stratum of indigenous Fijians. Though Rabuka's military government did not quite echo these calls, it made it clear by various means that it intended to regard Indo-Fijians-who, after all, comprised fifty per cent of the population-as no more than second rate citizens. For example, Rabuka formally 'allowed' Hindu Indo-Fijians to celebrate Diwali, but without firecrackers, out of 'security' considerations. With every passing day Indo-Fijians were dismissed from civil service positions to make room for the followers of the new order. Within the service sector, the granting of work permits was increasingly beset by discriminatory hurdles. Fiji's economy was highly dependent on the cultivation of sugarcane by Indo-Fijian farmers operating small holdings, and it appeared that the new regime was intent to keep them in that position, though as working ants without political rights. Parallels to South Africa and apartheid were continually being suggested.

'It was all inevitable' opined a student at an improvised panel discussion, 'the differences were too big and they were becoming bigger and bigger; it had to come to an explosion at some point'. An older expatriate said that he too had seen it coming for quite some time: 'the rapid growth, especially from the early 70s onwards, of a professional class of Indo-Fijians on the one hand, and of almost exclusive recruitment of indigenous Fijians into the army on the other, sooner or later was bound to lead to confrontations'. He continued: 'it was a big mistake for Fiji to have gone in for those Unifil tasks in Lebanon. That has led to much too rapid an expansion of the army, based on (indigenous) Fijian recruitment as an easy employment project'.

The inevitability of an ethnic confrontation was however widely disputed, by both indigenous Fijians and Indo-Fijians. 'Ethnic conflict is not what is at issue', one person argued, 'but it serves the new power holders-and some of the old ones-to portray it that way'. Who were these power holders? People knew. As one indigenous Fijian student said, 'it is not true that Fijians and Indians are living here in tension with one another. It is those other islanders who are making that up'. He was referring to the people of the Lau archipelago, and his insight pointed in two directions. In the first place there was a fundamental contradiction between the east and the west of Fiji. The 'west' comprises mainly the west of Viti Levu. It was here where the country's wealth was concentrated-sugar, gold, pine plantations, and 
tourism. In the west, indigenous Fijians and Indo-Fijians had been cohabiting for generations, perhaps out of economic necessity, but nevertheless generally on good terms. Yet the west had no political power. It was the 'east', comprising the Lau archipelago and part of Vanua Levu, which was the origin of many political power holders. For example, most members of the Great Council of Chiefs, a neotraditional political body set up by the colonial power and which had had its powers substantially expanded over time, came from the east. The divide ran roughly parallel to the distinction between the Melanesian and the Polynesian politico-cultural spheres of influence, which met in Fiji: Polynesian, with hierarchical political traditions in the east; Melanesian, with more egalitarian structures, in the west.

'Rabuka's coup is not supported in the western part, but it opens the door for a direct confrontation between east and west', noted an observer with a deep understanding of Fiji. If such a confrontation had occurred, it would not have been the first. It is well established that the west of Fiji was subjugated and brought under colonial control by a coalition of the British and chiefs from the east of Fiji. Moreover, and this was the second insight of the indigenous Fijian student mentioned above, the dominance of the east in Fiji's politics had increasingly allowed it to establish a grip on the sources of wealth in the west. As a consequence, some voices in the west spoke cautiously of secession and the establishment of a separate state in the west of Fiji, but the instruments needed to achieve anything of the sort were totally lacking. While a further expansion of the army was to take place, as always recruitment occurred primarily in the east.

The accumulation of economic and political power amongst a top layer of indigenous Fijians from the east of the country had been rapid and substantial, especially during the last term of office of the Alliance Party, which had witnessed a whole series of excesses and corruption scandals. 'It is the Alliance administration's poor performance and the new dichotomies it created which brought about increasing dissatisfaction among Fijians as well as Indians', a close observer quietly remarked. This in turn was a key factor leading to the emergence of the Fiji Labour Party (FLP) in 1985, and finally to the successful coalition of the FLP with the largely Indo-Fijian National Federation Party (NFP). Together, the FLP-NFP Coalition won the April 1987 elections and toppled the Alliance, putting an end to 
seventeen years of uninterrupted government control by Ratu Sir Kamisese Mara, a powerful figure with evident political talents but who during the last years of Alliance rule had become the centre of an increasingly tainted government.

The Coalition government led by Dr Timoci Bavadra was not radical or revolutionary. While it declared itself in favour of a nuclearfree Pacific, during its short time in office it pursued largely ad hoc solutions to immediate problems, particularly in the area of employment. Indeed, many insiders had felt that the Coalition government would not last long, falling apart as a result of internal contradictions between the FLP and the NFP. However, upon the formation of Bavadra's government, events moved rapidly. Soon after the Coalition's electoral victory sounds of protest were heard from the emergent Taukei, or 'native Fijian', movement, which accused IndoFijians of seeking to take over power in Fiji. The Taukei movement appeared at first a rather obscure entity, but when, after the elections, they provoked a series of disturbances and clashes, they reminded some older expatriates of the Nazi German 'brownshirts' prior to World War II. For others, they appeared reminiscent of Haiti's 'tomtoms'. Certainly, there were affinities. 'The Taukei', said a political scientist at the time, 'constitutes lumpenproletariat, consisting of fighting gangs arising from amongst unemployed youth with a vague sense of alliance with people from the Lau islands. They themselves also largely originate from there'. The Taukei undoubtedly prepared the climate for Rabuka's 14 May 1987 coup, and indeed following the coup Rabuka conducted a kind of public dialogue with the Taukei. As he put it, 'we are pursuing the same ends, but with different means'.

In common with the Taukei, Rabuka emphasised the indigenous Fijian character of Fiji's identity. However, indigenous Fijian identity was itself, in part, the product of the colonial encounter. This was most clearly witnessed in the introduction of the 'Sunday ban'. Following the coup, an absolute observance of Sunday as a 'day of rest' came into force. At a stroke, nothing was allowed on Sundays: no sports, no games, no picnics, no gardening nor car washing. No taxis or buses ran, and all shops were closed. However, the Sunday ban, despite appearing to be a bow to Christian fundamentalism, had a political objective. Rabuka's relationship with the Great Council of Chiefs was unclear. Rabuka's relationship with the politico-economic power bloc 
around Mara was also hazy. Indeed, Rabuka's relationship with the indigenous Fijian community as a whole was unclear. As one indigenous Fijian student, struggling to comprehend political changes that he really did not understand, put it: 'what is really being engineered here? What else is waiting us?'. Rabuka needed to solidify his position. The Sunday ban gained the support of many Methodist preachers and their congregations. It also offered Rabuka an opportunity to broaden his ideological base within the Taukei movement, many of whom were, paradoxically, actively practicing Christians, even if the macho jogging Taukei and the properly necktied Methodists appeared to be emotional antipoles.

The regime may have been trying to expand its base of support, but the competence within Rabuka's government to tackle the problems which it had both inherited and created, or indeed to even to acknowledge them, was extremely poor. 'One half of his team has a criminal record, while the other half has probably managed to escape it', judged a trained observer of Fiji's political scene and its actors. 'The economy is in crisis, and is running into a head-on disaster' was how one person saw it, while a policy researcher at the Reserve Bank of Fiji observed that following successive devaluations of the Fiji dollar 'the reserves have been reversed'. Everywhere, talk was of an economic 'nose-dive'. Whoever could afford to leave at least considered it, and in some sectors, particularly education and the public service, departures assumed massive proportions. Many companies retrenched staff, with instant effects in terms of people's ability to pay for rent, schools and buses; within a short space of time, noticeably fewer children were going to school. Tourism came to a standstill, notwithstanding spectacular budget offers being made to the US market. Several pine plantations went up in flames, in quiet protest. Indo-Fijian and indigenous Fijian sugarcane producers tried to protect themselves against potential food scarcities by reserving larger parts of their plots to grow food crops. Wealthy Indo-Fijian merchants and rich indigenous Fijians made sure their capital was out of the country as quickly as possible. 'If need be, we'll go back to the countryside, and to our traditional way of life', the Taukei claimed. 'But we don't want to go back to the land, and we would not even know how to cope there', a third generation urban indigenous Fijian woman stated. It was a heavy price to pay, not for democracy, but for its denial. 


\section{Words and meaning}

Many living in Fiji made caustic remarks about the reporting of the coup by foreign journalists. 'Most of them took it easy. They settled themselves in the lounge of the Grand Pacific Hotel and wrote a simplistic story about ethnic conflict between Indians and Fijians, exactly how Rabuka-and others behind him-would like to see it. We had hoped that at least the foreign press would correct that perverse image.' The reality was of course more complex, as was demonstrated to one of the authors when visiting USP as an external advisor to the History/Politics Department just a few weeks after the second coup. Towards the end of the visit the time came to share some impressions with members of the Department before drafting the final report. A staff meeting was thus arranged, just prior to departure, and quite central to the issues which were raised for discussion was, as a result of declining student enrolments and the changed political climate, the increasingly vulnerable position in which the History/Politics Department found itself within the university. The situation called for a new strategy, in which, through the offering of regionally specific, non-traditional history courses and policy-oriented politics courses, the Department would seek to build an interdisciplinary, development-focused approach. It thus seemed opportune for the History/Politics Department to dilute its disciplinary identity and, metaphorically, go 'underground'. This viewpoint was verbally communicated to the members of the Department during the course of the meeting.

Several weeks later, back in Europe, a clipping arrived in the mail from the Fiji Post of 31 October 1987. Under the bold headline 'Fight rages over Dutch scholar's activities', the paper carried a lengthy article on a controversy between the government and the university, which, at first glance, seemed to originate from another planet:

A verbal war continued yesterday between the Education Ministry and the University of the South Pacific over allegations that a visiting Dutch scholar had been advising USP staff to teach Marxism and Communism 'undercover'.

Yesterday, Education Minister Ratu Filimone Ralogaivau reiterated what he said early this week that the visitor had advised staff in the Social Science department to go 'underground' and teach the two subjects. Ratu Filimone said he had been reliably informed of these 
developments by a member of the staff who had been 'part of the discussions'. He said the move was designed to 'undermine the traditions of the Fijian people and thwart their present struggle in their own country'.

'I am surprised that this type of activity is being deliberately permitted in an institution funded by the taxpayers of Fiji. It appears that those who administer USP are setting out to force the hand of the present government...The leadership of the university continues to be insensitive about the inspirations of the Fijian people...The ViceChancellor must understand that the Laucala Bay campus stands on the sovereign territory of Fiji and that the university is subject to the laws of Fiji...'

In retrospect, what was interesting about this mini-crisis was not the different connotations of the word 'underground', but rather why its meaning was twisted. This was done to try and ensure that the external advisor's report was not considered, and thus ward off any possible attacks to the offering of an undiluted, 'traditional' history of Fiji and Pacific culture within the History/Politics Department.

Moreover, it was clear that the government's information had come from a staff member engaged in the teaching of traditional Fiji history and culture. That teaching had been done with the pre-colonial, colonial and the post-colonial periods all grasped within a single perspective of historical continuity, and with the colonial period being viewed as an interlude.

The interesting point about the controversy however was that it linked a perceived threat to departmental continuity and hegemony in the offering of traditional history courses to the threat to the integrity of the indigenous Fijian community imagined by the supporters of the new regime. Developing course offerings on the wider economic and social transformations to which Fiji had been subject during colonial times and after would have implied recognition of the roles that Fiji's various peoples - migrant as well as indigenous - had come to play in these transformations. It would have had to address the new social and political context that had come into existence in the wake of these historical changes. In contrast, restricting history courses to a focus on the continuity of traditional Fiji institutions to the present day made it possible to negate the vastly changed social and economic situation that had emerged through Fiji's history-as indeed the Taukei and Rabuka's government also appeared intent to do. The parallel between the micro politics in the Department and the macro situation in the 
country could hardly have been closer. Indeed, the politicisation of the issue at the particular time directly linked the question of course offerings to the central issue at stake in the country: identity in Fiji at the time and thereafter.

\section{Crisis and identities}

Until the time of the coups, identities in Fiji had appeared quite simple and straightforward. It was generally clear who could be referred to as 'Fijian' and it was similarly clear who could be identified as 'Indian' or 'Indo-Fijian'. Fuller integration had simply not been on the agenda.

Distinct identities were largely reflective of the separate niches the two main ethnic groups occupied within Fiji's economy and society. Social contacts across communities were relatively limited: except for some sections within the urban milieu, most indigenous Fijians and most Indo-Fijians interacted primarily amongst themselves rather than with members of a range of ethnic communities. Without any overt enmity or direct confrontations taking place, social relations had largely seemed unproblematic, and Fiji could readily be portrayed as a Pacific paradise by tour operators and others.

At another level, though, it was precisely this non-integrationconsciously engineered and preserved as it had been-which could be said to have constituted Fiji's main problematic feature. Superficially a multicultural society, its separate identities also signified unfulfilled social integration, social distance, differential access to political power and, though perhaps remotely, potential friction. Despite its various institutional mechanisms to ensure continued separate social and economic positions, such as in land, it is doubtful whether Fiji society in the longer run would have been able to sustain its seemingly appealing image alongside its lack of social integration.

The coups ruptured the seeming tranquility that people had been enjoying and brought to the fore this simmering issue. As a consequence, over the last decade Fiji has been deeply engaged in a process of re-appraising itself, which is leaving its imprint in terms of changing self-images and changing collective understandings about the future. Numerous questions about the shape of social and political relationships have been raised, and continue to be articulated from different perspectives. At one end of the spectrum, they range from querying continued separate designations which might be employed 
to keep ethnic groups apart, to asking whether ultimately all of Fiji's people may come to feel encouraged to call themselves 'Fijians'. At the other end of the spectrum, questions concern the preservation of authenticity, closely followed by a concern with the maintenance of the status quo. What both ends of the spectrum share is that they imply questions and concerns about the scope for power sharing and equity in any future constellation of social, cultural, political and economic arrangements in Fiji.

At the same time, probably more aspects of Fiji's society and economy have been subjected to probing analysis during this period than has happened at any time before. Moreover, at the policy and political level, numerous interventions-aggravating, ameliorating, or just sustaining the situation-have been undertaken following identification of the 'problem' in the wake of the coup. All this added substantially to changing relations, and perceptions of relations. Clearly, the period has not been an easy one. Indeed, in sociopsychological terms it is easy to see how the damage could have been irreparable.

\section{Appraising the aftermath}

Time has now come to recognise the importance of this aftermath; that is, to re-assess the net effects of all the self-searching and restructuring that has taken place during these twelve years, coupled to the equally significant social and political transitions that have been taking place on the ground. None of these have been minor and by themselves they signal the major differences, and possibly also the major gains, between the Fiji of today and that of twelve years ago-socially, economically, and politically.

Significantly, recognising the transformations that have occurred over the last decade or more also places a different light on Fiji's condition today, thus allowing the coups and their aftermath to be viewed within a broader historical and comparative perspective. From such a perspective some fresh reinterpretations might well suggest themselves. One overriding way of viewing the crisis so far has been - quite naturally—to equate it with a shattering of earlier expectations of progressive and peaceful co-habitation and integration, even though only a few people at the time may actually have been giving any thought as to how that might be brought about. 
Viewed from such a perspective, most of the different labels of national identity which have since been proposed either officially, such as 'Fiji Islanders', or unofficially, such as 'aboriginal' or 'ethnic' Fijians, could be seen as either reflecting fragmentation, or, at best, as perhaps rather feeble attempts at repair.

Dominant and natural as this range of interpretations has been, in due course they might possibly make room for different kinds of understanding, including some that might have appeared out of the question or contentious at an earlier stage. Notably, given the complex and virtually unprecedented demographic situation with which the colonial experience had left Fiji, the relative outsider, for one, might wonder whether the confrontations signaled by the coup and after could not be viewed as a kind of inevitable or 'necessary' crisis the country would have to pass through: necessary in the sense of being needed before the country would be able to arrive at a painful recognition of the common destinies which its peoples must share. Reflecting on the present, it is also necessary to remember from where Fiji has come. Colonial rule had left a country singularly handicapped to be handled as a unit, and a unity, thus potentially ranking it among the 'impossible' nation-states, countries such as Sudan, South Africa, Cyprus, and others. With a near even balance between the two main ethnic groups, with the two groups having largely separate economic spheres, with the two groups governed through institutions which emphasised separateness, and with powerful élites keen to preserve institutionally entrenched positions, Fiji evidently had a long way to go. Against that background, 1987 constituted a major, unprecedented shock which, it appears, has served as a prelude to the intensive soulsearching conducted over the past twelve years. If this reading is valid, it would just underscore the imperative, for Fiji's societal development and change, of constructing sound strategies oriented towards the country growing together, rather than growing apart.

Surely, though, such speculative thinking has its limits, and social science as a matter of principle will only sparingly offer space for it. Nor should any such reflections be construed to imply more generally that army coups can provide reliable routes towards possible reconciliation. Nonetheless, what is important is that due attention should be given to the many ways in which, provoked by the coups, segments of Fiji society and govemment during its aftermath have been attempting to come to terms with the country's basic realities- 
whether from narrowly competitive, even retrogressive, or from more genuinely constructive angles-thus beginning to address issues about Fiji's future in a more head-on fashion than they probably had done at any time earlier.

\section{Confronting Fiji futures}

The present volume reflects this ongoing search for alternatives and direction, and aims to make a contribution to the debates by illuminating a range of relevant issues from several strategic vantage points. Therefore, the volume is divided into two sections. The first section is entitled 'Politics, economics and social inequality' and begins with Chapter 2, 'The implementation of the Fiji Islands Constitution' by Yash Ghai. Ghai examines both the process by which the new 1997 Constitution of Fiji Islands was constructed, as well as its objectives, before going on to focus on three issues: the electoral system; multi-party government; and accountability. Some questions are raised concerning how the new Constitution will be implemented, using the word 'implementation' to denote the dynamics of the inner logic of the Constitution, the directions in which it compels, promotes or facilitates change, as well the contradictions within it which may obstruct the achievement of its objectives. Ghai stresses that the ultimate success of the new Constitution will depend upon the extent to which civil society becomes committed to its norms and values, and on this critical factor there are as yet no guarantees.

Chapter 3 is by Satendra Prasad and is entitled 'Fiji's 1999 general elections: outcomes and prospects'. The chapter demonstrates that the alternative voting system used in the 1999 general elections has been able to foster cooperation amongst Fiji's political parties, and that this cooperation has been reinforced by the introduction of multiparty government. However, the new voting system has not been able to eliminate the recourse to ethnicity as a tool of political mobilisation. Ironically, the use of ethnicity may not have occurred in those seats 'reserved' for Fiji's main ethic communities; rather, it may have occurred in those seats for which the entire electorate is eligible to cast its vote. Moreover, where it has fostered cross-community cooperation, this has been amongst élites; it has not occurred amongst the people. Nonetheless, as a national referendum on the 1997 Constitution, the 1999 general elections demonstrate that it has received an overwhelming mandate from the peoples of Fiji. 
Chapter 4 is entitled 'Fiji's economy: the challenge of the future' and is by Ardeshir Sepehri and Haroon Akram-Lodhi. The chapter begins by providing an overview of the evolution of Fiji's macroeconomic structure during the post-independence period, placing particular emphasis on changes occurring during the period between 1987 and 1992. It then focuses upon assessing the impact of domestic savings, public sector spending and external resources, including Fiji's preferential access to the European Union for its sugar exports, on the growth path of the Fiji economy by specifying a threegap model of growth in Fiji for the period 1971 to 1996. Once the three-gap model is estimated, the parameters of the model are used to simulate the period between 1997 to 2001 under four alternative growth path 'scenarios'. These scenarios examine the impact of a gradual elimination of Fiji's preferential access to the European Union, and thus a substantial reduction in the availability of foreign resources, which, should it occur, would have a major affect on the growth of the economy. Sepehri and Akram-Lodhi demonstrate that the challenge for Fiji's policy makers is to intensify export diversification efforts. They suggest that in order to develop a set of coherent and consistent policies to promote export diversification there is a pressing need to reduce the 'ethnicisation' of economic policy, arguing that a reduction in the role played by ethnicity in the formulation and implementation of economic policies may improve the efficiency of state intervention in the economy and in so doing contribute to enhanced economic performance.

Chapter 5, 'Institutional rigidities and economic performance in Fiji', is by Biman Prasad and Sunil Kumar. Consistent with Chapter 4, Prasad and Kumar argue that the key constraints to improved economic performance in Fiji are a set of institutional rigidities. Supply-side structural adjustment policies in Fiji have, according to Prasad and Kumar, been based upon a neoclassical model which assume institutional structures as given and thus fail to consider their potential role as a constraint. Yet, argue the authors, institutional rigidities pervade the Fiji economy. Long-term growth will only increase if these institutional rigidities are addressed and resolved. Prasad and Kumar provide a case study of property rights in land to illustrate their main argument, arguing that key land tenure institutions are inefficient, and suggesting that this inefficiency has implications for investment, production and distribution. 
Chapter 6 is by John Cameron and is entitled 'Confronting social policy challenges in Fiji'. Cameron examines the extent of the challenge confronting civil society and the state in Fiji in seeking to redistribute social and economic uncertainty, improve the degree of equality within society, and in so doing build 'social wealth'. Adopting a perspective similar to that found in Chapter 5, Cameron offers a critique of the neoliberal approach to social inequality and argues that the new institutional economics offers a countervailing approach rooted in distinctive moral and political perspectives which emphasise the interaction between civil society, state institutions and imperfect markets in facilitating improvements in the degree of equality within a society. In light of this framework, Cameron argues that the challenge confronting the state in Fiji is not in the detail of policy design but rather in the need to build on and invest in existing social wealth so as to institutionalise positive socio-economic processes. Three possible policy interventions which could institutionalise positive socioeconomic processes are briefly examined: health and nutrition, education and community relations. Cameron argues that the construction of a less unequal, more socially-inclusive, multicultural polity requires that state social policy actively support those civil society institutions in both major ethnic groups which have facilitated social wealth formation and a good quality of life for many of Fiji's peoples.

Chapter 7, by Ganesh Chand, explores an important source of social inequality in its examination of 'Labour market deregulation in Fiji'. Chand looks at the background to deregulation policies, the objectives of the deregulation drive, the key mechanisms for deregulating the labour market, and some consequences of deregulation. Chand argues that the deregulation process was part of a wider set of structural adjustment policies which Fiji began adopting in the mid 1980s. The military coup and the subsequent collapse of the economy provided the opportunity for Fiji to push ahead with the adjustment program. As the gist of the new policy package was export-oriented industrialisation, deregulation was to align the labour market with this objective. The consequences of deregulation are demonstrated by Chand to have been a continuing decline in the unionisation rate, most notably in the manufacturing sector but more generally in the private sector; a rise in industrial disputes but a fall in the number and intensity of strikes; a fall in real wages; and an increasing prominence 
of female workers in wage employment. Chand notes that the new Constitution has repealed some of the decrees which were promulgated during 1991 and 1992, stressing that this suggests that the institutional framework structuring labour market outcomes in the early 1990s was regarded by many of the peoples of Fiji as unjust. However, Chand argues, repeal has occurred after a significant transformation in Fiji's labour market has already occurred. Labour market deregulation has therefore already had an impact that will be felt in the years to come.

Chapter 8, entitled 'Women in post-coup Fiji: negotiating work through old and new realities', examines a second source of social inequality, that of gender relations. Written by Jacqueline Leckie, the chapter explores the ways in which the political economy of post-coup Fiji has profoundly shaped women's lives, expectations and identities. Predicated on the proposition that it is futile to separate work from other component's of women's lives, Leckie argues that change has been a reflection of women's cultures, the legacy of colonialism, the education system, the impact of the post-coup regime, and globalisation. According to Leckie, for women gender is the central thread through these changes; but they are also linked to other identities and hierarchies, and especially those of ethnicity and class. In part, she argues, this sheds light on the contradictory responses to change from women. For most women these responses are not polarised choices but rather represent what may seem to be a neverending balancing act between old and new realities, in which personal and collective identities are negotiated to varying degrees. Contestation over tradition, culture and political rights has thus been on going since the coups, although it was not given legitimate public space until the review of the 1990 Constitution. Leckie concludes by arguing that given the cultural and economic realities of the present, how Fiji's new constitution will improve women's rights remains a vitally important question.

In Chapter 8 Leckie introduces the idea that social identity is rooted in political and economic processes. This idea is explored in more detail in the second section of Confronting Fiji Futures, 'The "Fijian" question', which offers detailed analysis on the political economy of indigenous Fijian identity. The section begins with Chapter 9, 'The problematics of reform and the "Fijian" question', by William Sutherland. Sutherland is concerned with the impact of postcoup reforms on the 'Fijian' question which, at its most elementary, 
comes down to a simple question: who is a Fijian? Sutherland argues that up to the early 1990s the state's economic reform agenda was driven primarily by nationalist indigenous Fijian demands but that from the mid 1990s, faced with increasing external pressures for greater liberalisation, the state not only picked up the pace and scope of reform but also increasingly had to distance itself from its nationalist agenda. In so doing the state alienated the political constituency on which it depended most critically. By the late 1990s the level of indigenous Fijian disaffection had grown, and the Fijian question remained unresolved. Sutherland concludes by demonstrating that how the Fijian question is managed in the future will be critical to the country's prospects for economic growth and political stability.

Chapters 10 and 11 offer two case studies of the 'Fijian' question. Chapter 10 is entitled 'Addressing inequality? Economic affirmative action and communal capitalism in post-coup Fiji' and is by Steven Ratuva. Having defined 'communal capitalism', Ratuva provides an overview of the economic affirmative action policies intended to benefit indigenous Fijians in the wake of the 1987 coups. A case study of communal capitalism, that of the Fijian Holdings Company Limited, is presented by Ratuva because it is the flagship of indigenous Fijian communal investment, and is seen as a success story in as far as communal capitalism is concerned, yet it manifests some fundamental contradictions, which are explored in the chapter. In these explorations, Ratuva is able to substantiate the profound doubts he has about the benefits of economic affirmative action in Fiji, in large part because they have primarily benefited a small minority of indigenous Fijians.

In Chapter 11, Holger Korth examines 'Ecotourism and the politics of representation in Fiji'. Korth demonstrates that the main thrust behind ecotourism development in Fiji has been the re-invention of Fiji as a 'destination image' which, in its production and consumption, centers on nature and indigenous Fijian ethnicity. Seemingly progressive in its environmentalist sensitivities, Korth shows that the development of ecotourism in Fiji has been driven by segments of the state apparatus. However, ecotourism development in Fiji has, according to Korth, been predicated upon the conservation of the social, cultural and natural ecology. Korth argues that while sustainable development requires this, it also requires more: the democratisation of decision-making processes, the equitable distribution of resources, 
and equal opportunities across the age and gender divide. Ecotourism has failed to contribute to these. Closely examining certain aspects of ecotourism development, Korth shows that such development reflects ethnic divisions and prevalent post-coup political sentiments. Korth notes that it is, in this light, not surprising that ecotourism has had minimal economic impact.

Chapter 12, by Robbie Robertson, concludes the volume. Entitled 'Retreat from exclusion? Identities in post-coup Fiji', Robertson argues that Fiji has only partially retreated from the extremist nationalism that underlay the 1987 coups. Robertson notes that despite considerable achievements in the new 1997 Constitution, the nation still has to come to terms with its past. In particular, Robertson highlights issues of identity-including ownership of the national name - which remain largely unresolved. Robertson illustrates the complex paradox of identity in Fiji by examining the changing views of Sitiveni Rabuka on inter-community relations. This paradox, Robertson argues, means that the potential remains for powerful but fractious class interests to exploit ethnocentrism in order to maintain advantage, and thereby once more push the country back towards heightened communal division.

The chapters offered in this collection represent a stocktaking of the rethinking processes that have been underway in Fiji since the coups. They point to the significant ways in which social, economic and political relations have been shifting since 1987, as well as to emerging changing perspectives on these relations and their future. In this regard, the chapters by Robertson, Sutherland, Ratuva, Leckie and Chand, amongst others, represent thoughtful discussions of different levels of post-coup transition and the re-interpretations to which they have given rise. The picture that emerges is one of a society that seems much better equipped now than it was twelve years ago to face and take up the challenges it is confronted with, and to recognise that integration on various fronts is going to be arduous, but nevertheless the only route worth going.

The book's timeliness in this respect has been underscored by the spectacular and largely unexpected outcomes of the 1999 Fiji elections. The election results themselves have been indicative of the significant social re-orientation that has occurred in recent years in response to, or despite, all the governmental and non-governmental doctoring that was done. Satendra Prasad contributes an insightful analysis of the 
elections in this volume. Evidently, changing social realities have given rise to a new and autonomous social dynamic which, more emphatically than ever before, begins to defy the ethnic categorisations once thought descriptive of basic social divisions. The importance of changing social realities in the Fiji context also lies in demonstrating that even complex institutionalised strings and knots cannot keep voters' feet tied all the time. As Robertson remarks, what official resources have failed to do, the popular vote may possibly achieve.

Naturally, the drastically changed political constellation the elections have inaugurated invites another fresh wave of rethinking on the key issues confronting Fiji. It is hoped that the chapters that follow can serve as an aid in that process: many of the questions explored by the authors will no doubt feature prominently on the policy agenda and in public debate in the years to come.

\section{Endnote}

1. From W.B. Yeats The Second Coming:

Turning and turning in the widening gyre

The falcon cannot bear the falconer;

Things fall apart; the center cannot hold;

Mere anarchy is loosed upon the world.

All quotations contained within this chapter are taken from the field notes of Martin Doornbos, collected and collated during his 1987 visit to Fiji. 
This text is taken from Confronting Fiji Futures, edited by A. Haroon Akram-Lodhi, published 2016 by ANU eView, The Australian National University, Canberra, Australia. 